\title{
Antitumor Activity of Ionic Liquids Based on Ampicillin
}

\author{
Ricardo Ferraz, ${ }^{[a, b]}$ João Costa-Rodrigues, ${ }^{*[c]}$ Maria H. Fernandes, ${ }^{[c]}$ Miguel M. Santos, ${ }^{[a]}$ \\ Isabel M. Marrucho, ${ }^{[\mathrm{d}]}$ Luís Paulo N. Rebelo, ${ }^{[\mathrm{d}]}$ Cristina Prudêncio, ${ }^{[\mathrm{b}, \mathrm{e}]}$ João Paulo Noronha, ${ }^{[\mathrm{a}]}$ \\ Željko Petrovski, ${ }^{*[a]}$ and Luís C. Branco*[a]
}

Significant antiproliferative e $\mathrm{f} f$ eagainsst various tumor cell lines were observed with novel ampicillin salts as ionic liquids. The combination of anionic ampicillin with appropriate ammonium, imidazolium, phosphonium, and pyridinium cations yielded active pharmaceutical ingredient ionic liquids (API-ILs) that show potent antiproliferative activities against five different human cancer cell lines: T47D (breast), PC3 (prostate), HepG2 (liver), MG63 (osteosarcoma), and RKO (colon). Some API-ILs showed $\mathrm{IC}_{50}$ values between $5 \mathrm{a} \mathrm{n} \mathrm{d} 2 \mathrm{~nm}$, activities that stand in dramatic contrast to the negligible cytotoxic activity level shown by the ampicillin sodium salt. Moreover, very low cytotoxicity against two primary cell lines-skin (SF) and gingival fibroblasts (GF) -indicates that the majority of these API-ILs are nontoxic to normal human cell lines. The most promising combination of antitumor activity and low toxicity toward healthy cells was observed for the 1-hydroxyethyl-3-methylimidazolium-ampicillin pair ([ $\left.\left.\mathrm{C}_{2} \mathrm{OHMIM}\right][\mathrm{Amp}]\right)$, making this the most suitable lead API-IL for future studies.

Researchers in the pharmaceutical industry are currently facing a series of challenges in the discovery of innovative and effective drugs and their subsequent therapeutic applications. Most active pharmaceutical ingredients (APIs) are available in solid form, a state that frequently suffers from polymorphic conversion, low solubility, and a variety of other factors that affect the final bioavailability. Various pharmaceutical salts, in sodium

[a] Dr. R. Ferraz, Dr. M. M. Santos, Prof. J. P. Noronha, Dr. Ž. Petrovski, Dr. L. C. Branco

Departamento de Química, REQUIMTE-CQFB, Faculdade de Ciências e Tecnologia da Universidade Nova de Lisboa, 2829-516 Caparica (Portugal) E-mail:I.branco@fct.unl.pt z.petrovski@fct.unl.pt

[b] Dr. R. Ferraz, Prof. C. Prudêncio

Ciências Químicas e das Biomoléculas, Escola Superior de Tecnologia da Saúde do Porto do Instituto Politécnico do Porto, Rua Valente Perfeito 322, 4400-330 Vila Nova de Gaia (Portugal)

[c] Prof. J. Costa-Rodrigues, Prof. M. H. Fernandes

Laboratório de Farmacologia e Biocompatibilidade Celular, Faculdade de Medicina Dentária, Universidade do Porto, Rua Dr. Manuel Pereira da Silva 4200-393 Porto (Portugal)

E-mail:jrodrigues@fmd.up.p

[d] Dr. I. M. Marrucho, Prof. L. P. N. Rebelo

Instituto de Tecnologia Química e Biológica, ITQB, Universidade Nova de Lisboa, Av. da República Estação Agronómica Nacional, 2780-157 Oeiras (Portugal)

[e] Prof. C. Prudêncio

Centro de Farmacologia e Biopatologia Química (U38-FCT), Faculdade de Medicina da Universidade do Porto (FMUP) (Portugal) or potassium form, have been developed to improve aqueous solubility. Ionic liquids (ILs) are a peculiar class of organic salts with melting points below $100^{\circ} \mathrm{C}$ which have been the focus of increasing interest in the scientific community and industry; the large number of potential cation-anion combinations allows a variety of tunable interactions and applications. ${ }^{[1]}$ One of the most promising applications of ILs is in the so-called third generation of ILs, that is, their arrangement with APIs to generate API-ILs. ${ }^{[2-6]}$ Successful buffer-controlled procedures for the preparation of API-ILs containing the anion of ampicillin (a well-known antibiotic) combined with members of four organic cation classes (ammonium, imidazolium, phosphonium, and pyridinium) have been reported. ${ }^{[7-9]}$ These API-IL combinations can be an innovative solution to the polymorphic behavior of certain drugs, and can also improve water solubility, permeability, and therefore bioavailability. The appropriate arrangement of a biocompatible anion or cation with a specific drug can be relevant in modifying the corresponding biopharmaceutical drug classification system $(B C S)^{[2,4,10-12]}$ as well as their drug formulation process.

The important question regarding the toxicity of the API counter-ion in ILs has been the major cause behind the delayed entry of ILs into the wider biosciences field. ${ }^{[5,13]}$ Toxicities toward microorganisms and eukaryotic cell cultures cover the entire range of biocidal potencies, from rather inactive molecular solvents that are biocompatible, up to high concentrations in aqueous solutions for pharmaceutical applications, ${ }^{[2,4,12]}$ and even as potential in vitro anticancer agents. ${ }^{[8,10]}$ Antimicrobial activities against Escherichia coli (susceptible and resistant), Klebsiella pneumoniae, Staphylococcus aureus, and Enterococcus faecium have been reported for some ampicillin organic salts in comparison with sodium ampicillin ([Na][Amp]) ${ }^{[9,14]}$ Consequently, the development of novel anticancer drugs that are less toxic than currently available chemotherapeutic treatments can also be pursued with ionic liquids. ${ }^{[3,4,12]}$ Herein we describe the antiproliferative effects of several previously synthesized ampicillin ILs (Figure 1) against various tumor cell lines.

Table 1 summarizes the antitumor activities $\left(I_{50}\right.$ and $\left.L D_{50}\right)$ of the ampicillin-anion-based ILs against two primary human cell types: skin (SF) and gingival fibroblasts (GF). [Na][Amp] was used as control, and as is evident from the data listed in Table 1, it is one of the least toxic. The $\mathrm{IC}_{50}$ value was not detected in the concentration range used against $\mathrm{SF}$, and the $\mathrm{IC}_{50}$ value toward GF was $109.1 \mu \mathrm{M}$. In comparing the other synthesized compounds with $[\mathrm{Na}][\mathrm{Amp}]$, the most toxic toward the healthy human cell lines are $\left[\mathrm{P}_{6,6,6,14}\right][\mathrm{Amp}]$ and $\left[\mathrm{C}_{16} \mathrm{Pyr}\right][\mathrm{Amp}]$ (lowest $I_{50}$ values). Ammonium-based ILs [TEA][Amp] and 


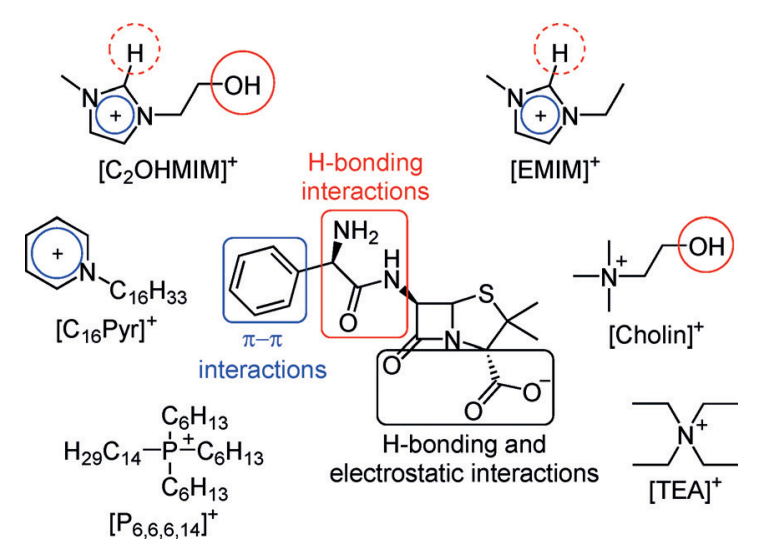

Figure 1. Structures of ampicillin salts and their possible cation-anion interactions. Details of their synthesis are available in the Supporting Information.

Table 1. Antitumor activities of the prepared ILs against two primary human cell types.

\begin{tabular}{|c|c|c|c|}
\hline \multirow[t]{2}{*}{ Compd } & & \multicolumn{2}{|c|}{ Cell line } \\
\hline & & $\mathrm{SF}^{[\mathrm{b}]}$ & $\mathrm{GF}^{[\mathrm{c}]}$ \\
\hline \multirow{2}{*}{ [TEA][Amp] } & $\mathrm{IC}_{50}[\mu \mathrm{M}]$ & $N D^{[d]}$ & $\mathrm{ND}^{[\mathrm{d}]}$ \\
\hline & $\mathrm{LD}_{50}[\mu \mathrm{M}]$ & $\mathrm{ND}^{[\mathrm{d}]}$ & $>58.040$ \\
\hline \multirow{2}{*}[\mathrm{P}_{6,6,6,6,14}]{$[\mathrm{Amp}]$} & $\mathrm{IC}_{50}[\mu \mathrm{M}]$ & $>0.249$ & $>0.173$ \\
\hline & $\mathrm{LD}_{50}[\mu \mathrm{M}]$ & $>0.249$ & $>0.176$ \\
\hline \multirow{2}{*}[\mathrm{C}_{16}\mathrm{Pyr}]{$[\mathrm{Amp}]$} & $\mathrm{IC}_{50}[\mu \mathrm{M}]$ & $>0.032$ & $>0.012$ \\
\hline & $\mathrm{LD}_{50}[\mu \mathrm{M}]$ & $>0.815$ & $45.510 \pm 0.131$ \\
\hline \multirow{2}{*}{ [Cholin][Amp] } & $I C_{50}[\mu \mathrm{M}]$ & $48.480 \pm 0.571$ & $N D^{[d]}$ \\
\hline & $\mathrm{LD}_{50}[\mu \mathrm{M}]$ & $49.790 \pm 0.368$ & $\mathrm{ND}^{[\mathrm{d}]}$ \\
\hline \multirow{2}{*}{ [EMIM][Amp] } & $\mathrm{IC}_{50}[\mu \mathrm{M}]$ & $>6.366$ & $>0.853$ \\
\hline & $\mathrm{LD}_{50}[\mu \mathrm{M}]$ & $>6.366$ & $>9.357$ \\
\hline \multirow{2}{*}[\mathrm{C}_{2}\mathrm{OHMIM}]{$[\mathrm{Amp}]$} & $\mathrm{IC}_{50}[\mu \mathrm{M}]$ & $>5.084$ & $>0.462$ \\
\hline & $\mathrm{LD}_{50}[\mu \mathrm{M}]$ & $>22.600$ & $30.470 \pm 0.428$ \\
\hline \multirow{2}{*}[\mathrm{Na}]{$[\mathrm{Amp}]^{[\mathrm{a}]}$} & $I C_{50}[\mu \mathrm{M}]$ & $N D^{[d]}$ & $>109.100$ \\
\hline & $\mathrm{LD}_{50}[\mu \mathrm{M}]$ & $>8.104$ & $>109.100$ \\
\hline
\end{tabular}

[a] [Na][Amp] was used as a control. [b] Skin fibroblasts. [c] Gingival fibroblasts. [d] Not detected in the concentration range used. [Amp] = ampicillin anion, $[T E A]=$ tetraethylammonium, $\left[\mathrm{P}_{6,6,6,14}\right]=$ trihexyltetradecylphosphonium, $\left[\mathrm{C}_{16} \mathrm{Pyr}\right]=$ cetylpyridinium, $[$ Cholin $]=$ choline, $[\mathrm{EMIM}]=1$-ethyl-3methylimidazolium, $\quad\left[\mathrm{C}_{2} \mathrm{OHMIM}\right]=1$-hydroxyethyl-3-methylimidazolium. Data were obtained from three independent experiments, and each assay was performed in three replicates; for all experiments the associated errors $( \pm S D$ ) did not exceed $5 \%$.

[Cholin][Amp] were found to be the least toxic, with imidazolium-based ILs [EMIM][Amp] and [ $\left.\mathrm{C}_{2} \mathrm{OHMIM}\right][\mathrm{Amp}]$ having $\mathrm{IC}_{50}$ values in between. These results are in agreement with published work showing that higher hydrophobicity and increased alkyl chain length lead to increased toxicity. ${ }^{[13,15]}$

Table 2 summarizes the antitumor activities of the ampicillinbased ILs against several human cancer cell lines: T47D (breast), PC3 (prostate), HepG2 (liver), MG63 (osteosarcoma), and RKO (colon). Figure 2 shows some representative experimental data used to calculate these values listed. Among all compounds tested, the 3-(2-hydroxyethyl)-1-methylimidazolium-ampicillin salt ([ $\left.\left.\mathrm{C}_{2} \mathrm{OHMIM}\right][\mathrm{Amp}]\right)$ possesses the greatest selectivity and antiproliferative activity against these five cancer cell lines. Some lipophilic phase-transfer agents (coun- ter-ions) can significantly assist the transfer of highly polar molecules (different APIs) through prokaryotic and eukaryotic membranes, thereby improving drug activity. However, we have also shown that the lipophilicity of the counter-ion alone does not necessarily solve all API problems, but can contribute to the improvement of certain physicochemical properties such as aqueous solubility and octanol-water partition coefficients $\left(K_{\text {ow }}\right) \cdot{ }^{[5]}$ In this context, the outstanding antitumor activity of ampicillin salts can be explained by the stronger and more stable cation-anion pairings brought about by the expected hydrogen bonding and $\pi-\pi$ interactions, as well as electrostatic interactions that can be established between the ampicillin anion and certain organic cations. For example, $\left[\mathrm{C}_{2} \mathrm{OHMIM}\right]$ can establish hydrogen bonding and $\pi-\pi$ interactions, as illustrated in Figure 1. As indicated in Figure 1 and Table 2, the best results were observed for the cases of stronger and more stable cation-anion interactions, where the appropriate counter-ion acts as a more lipophilic drug carrier.

Ampicillin sodium salt ([Na][Amp]), which is a standard antibiotic in current use, only shows cytotoxic activity toward PC3 and RKO cell lines, with respective $\mathrm{IC}_{50}$ values greater than 0.597 and $2.406 \mu \mathrm{M}$. Moreover, its antiproliferative activity is very weak toward the cell lines studied, with the exception of HepG2. However, it is quite well tolerated by primary fibroblasts, namely GF. Markedly different antitumor results have been observed by pairing distinct organic cations with ampicillin. For instance, whereas [TEA][Amp] is highly cytotoxic toward MG63 and T47D cells, [Cholin][Amp] was found to be particularly selective for the RKO cell line. In addition, this APIIL only shows significant antiproliferative behavior toward MG63 cells. In contrast to other bulky cations, the high cytotoxic effect of [Cholin][Amp] toward MG63 cancer cells and high selectivity away from noncancerous cells can be partially attributed to its high water solubility and partition coefficient, ${ }^{[5]}$ which facilitate the transport of the xenobiotic (in this case, ampicillin) to the cytosol of cancer cells. Moreover, this capacity is particularly enhanced in these cells, as the [Cholin] cation is a nutrient. ${ }^{[3,16]}$ On the other hand, [EMIM][Amp] is particularly selective against $\mathrm{RKO}$, with an $\mathrm{IC}_{50}$ value $>0.269 \mu \mathrm{M}$. Considering the previously reported physicochemical properties of these compounds, ${ }^{[5]}$ the enhanced cytotoxic activity toward particular cancer cell lines as well as low toxicity against primary fibroblasts can be related to the greater lipophilic character of these cations than the sodium analogue.

$\left[\mathrm{C}_{2} \mathrm{OHMIM}\right][\mathrm{Amp}]$ was found to be a very potent antitumor agent against all cancer cell lines studied, with $\mathrm{IC}_{50}$ and $\mathrm{LD}_{50}$ values in the ranges of $0.146-0.738 \mu \mathrm{M}$ and $0.297-4.197 \mu \mathrm{M}$, respectively. A similar observation was made for the $\left[\mathrm{P}_{6,6,6,14}\right]$ [Amp] IL; however, it is 90 - to 173 -fold more toxic toward primary fibroblasts. This finding is not surprising, as the very high toxicity of compounds with this cation toward other cell lines was described previously, with similar $\mathrm{IC}_{50}$ and $\mathrm{LD}_{50}$ values. ${ }^{[17,18]}$ $\left[C_{16}\right.$ Pyr $][A m p]$, which showed $I C_{50}$ values in the low nanomolar range toward MG63 and T47D cells, was also shown to be fairly toxic toward fibroblasts, namely SF. This observation is in line with that previously reported for the $\left[\mathrm{C}_{16} \mathrm{Pyr}\right]$ cation, ${ }^{[19,20]}$ despite its frequent application in pharmaceutical formulations. 

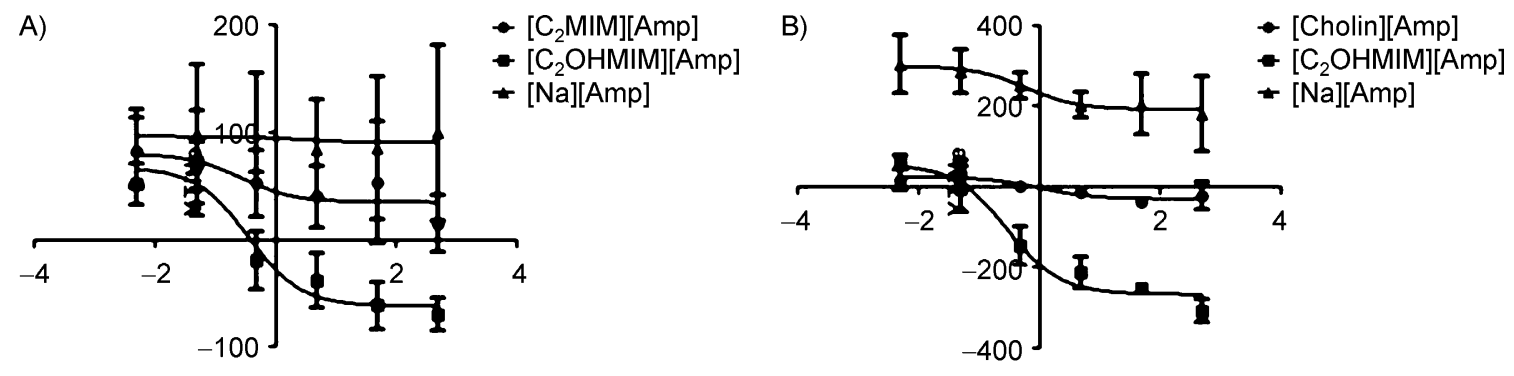

$\log [\mathrm{compd}] / \mu \mathrm{M}$

$\log [\mathrm{compd}] / \mu \mathrm{M}$
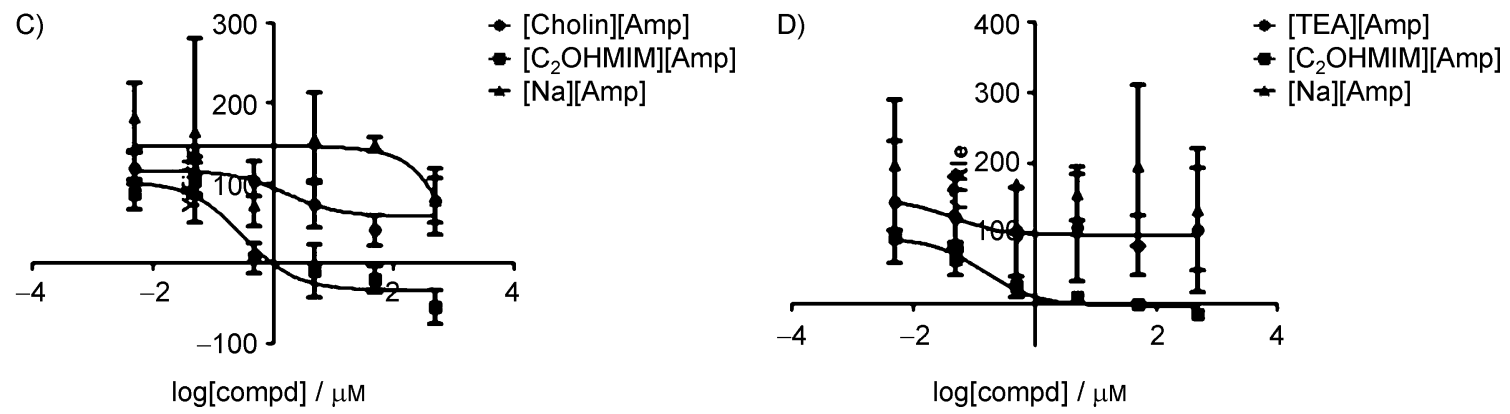

Figure 2. Experimental $I C_{50}$ data for the most representative compounds toward A) RKO, B) PC3, C) HepG2, and D) T47D cell lines. Data are the mean \pm SD determined from three separate experiments; each assay was performed in three replicates.

\begin{tabular}{|c|c|c|c|c|c|c|}
\hline \multirow[t]{2}{*}{ Compd } & & \multicolumn{5}{|c|}{ Cell line ${ }^{[b]}$} \\
\hline & & MG63 & HepG2 & T47D & PC3 & RKO \\
\hline \multirow{2}{*}{ [TEA][Amp] } & $\mathrm{IC}_{50}[\mu \mathrm{M}]$ & $>0.030$ & $N D^{[d]}$ & $>0.042$ & $>35.650$ & $>56.700$ \\
\hline & $\mathrm{LD}_{50}[\mu \mathrm{M}]$ & $1.368 \pm 0.020$ & $0.095 \pm 0.008$ & $>43.990$ & $>58.920$ & $68.370 \pm 0.511$ \\
\hline$\left[P_{6,6,6,14}\right]$ & $\mathrm{IC}_{50}[\mu \mathrm{M}]$ & $0.312 \pm 0.019$ & $>0.322$ & $>0.264$ & $>0.354$ & $>0.180$ \\
\hline [Amp] & $\mathrm{LD}_{50}[\mu \mathrm{M}]$ & $>0.312$ & $>0.322$ & $>4.970$ & $9.335 \pm 0.179$ & $>11.860$ \\
\hline$\left[\mathrm{C}_{16}\right.$ Pyr $]$ & $\mathrm{IC}_{50}[\mu \mathrm{M}]$ & $>0.011$ & $\mathrm{ND}^{[\mathrm{d}]}$ & $>0.005$ & $132.700 \pm 3.593$ & $>0.226$ \\
\hline [Amp] & $\mathrm{LD}_{50}[\mu \mathrm{M}]$ & $>183.200$ & $\mathrm{ND}^{[\mathrm{d}]}$ & $\mathrm{ND}^{[\mathrm{d}]}$ & $>132.700$ & $59.170 \pm 0.095$ \\
\hline [Cholin] & $\mathrm{IC}_{50}[\mu \mathrm{M}]$ & $>0.017$ & $>1.619$ & $>110.900$ & $>0.982$ & $N D^{[d]}$ \\
\hline [Amp] & $\mathrm{LD}_{50}[\mu \mathrm{M}]$ & $>0.031$ & $>5.765$ & $>110.900$ & $17.160 \pm 0.514$ & $>0.707$ \\
\hline [EMIM] & $\mathrm{IC}_{50}[\mu \mathrm{M}]$ & $>1.122$ & $>24.270$ & $N D^{[d]}$ & $>29.990$ & $>0.269$ \\
\hline$[\mathrm{Amp}]$ & $\mathrm{LD}_{50}[\mu \mathrm{M}]$ & $>1.122$ & $>24.270$ & $32.370 \pm 0.121$ & $>31.020$ & $>209.700$ \\
\hline$\left[\mathrm{C}_{2} \mathrm{OHMIM}\right]$ & $\mathrm{IC}_{50}[\mu \mathrm{M}]$ & $>0.738$ & $>0.319$ & $>0.146$ & $>0.297$ & $>0.359$ \\
\hline [Amp] & $\mathrm{LD}_{50}[\mu \mathrm{M}]$ & $>1.240$ & $>0.4040$ & $>0.498$ & $>0.297$ & $>0.362$ \\
\hline \multicolumn{7}{|c|}{ 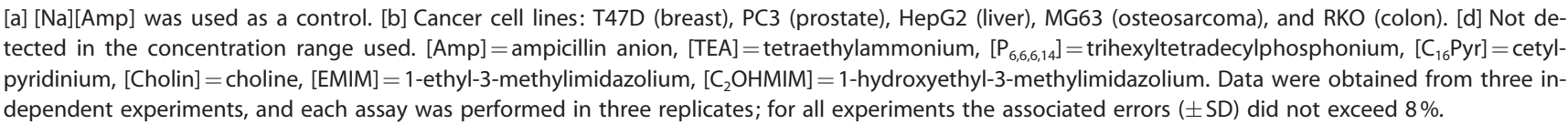 } \\
\hline
\end{tabular}

The particularly high toxicity toward cancerous and/or normal cells shown by these three API-ILs is probably related to their high amphiphilic character relative to the analogous sodium salt, ${ }^{[5]}$ this promotes cell membrane permeation and consequently their efficiency.

Notably, choline salts with acetate, propanoate, butanoate, hexanoate, and pivalate anions showed $\mathrm{IC}_{50}$ values $>10 \mu \mathrm{M}$ toward MCF-7 lung cancer cells which increase with the length of the carbon chain..$^{[21]}$ Usually, other ionic liquids containing quaternary ammonium cations are not cytotoxic toward cancer cell lines. ${ }^{[8]}$ As previously reported by Malhotra et al. ${ }^{[9]}$ methyli- midazolium-based ionic liquids only show cytotoxic activity if the alkyl side chain contains more than 11 methylene units.

In conclusion, the combination of ampicillin with organic cations in place of sodium has yielded novel ionic liquids that show low $\mathrm{IC}_{50}$ and $\mathrm{LD}_{50}$ values against five different cancer cell lines: T47D (breast), PC3 (prostate), HepG2 (liver), MG63 (osteosarcoma), and RKO (colon). Furthermore, very low toxicity against two primary cell lines-skin (SF) and gingival fibroblasts (GF) -indicates that the majority of these compounds are nontoxic to certain healthy human cells. Outstanding cytotoxic and antiproliferative activities against several tumor cell 
lines, with $\mathrm{IC}_{50}$ and $\mathrm{LD}_{50}$ values in the low micromolar range, associated with low activity against primary fibroblasts was observed for $\left[\mathrm{C}_{2} \mathrm{OHMIM}\right][\mathrm{Amp}]$. On the other hand, [TEA][Amp], [Cholin][Amp], and [EMIM][Amp] showed $I_{50}$ values in the nanomolar or low micromolar range against some of the cancer cell lines tested, as well as very low toxicity toward normal cells. These data make these API-ILs the most promising lead compounds for future in vivo studies. Importantly, selection of the appropriate counter-ions can explain these antitumor activities due to the stronger and more stable cationanion interactions relative to the sodium analogue. Therefore, suitable organic cations can establish efficient ion pairs, acting as lipophilic drug carriers as well as improving water solubility, permeability, and bioavailability of the final pharmaceutical salts.

\section{Experimental Section}

All compounds were prepared by using an optimized and sustainable method described in the Supporting Information. ${ }^{[5]}$ The synthesized compounds were then evaluated for their antiproliferative activity against the following human cancer cell lines: T47D (ductal breast epithelial tumor), PC3 (prostate cancer), HepG2 (hepatocellular liver carcinoma), MG63 (osteosarcoma), and RKO (colon cancer). Two primary human cell types, skin and gingival fibroblasts (SF and GF, respectively), were also tested. Cells were maintained in $\alpha$-minimal essential medium ( $\alpha$-MEM) containing $10 \%$ fetal bovine serum, $100 \mathrm{IU} \mathrm{\textrm {mL } ^ { - 1 }}$ penicillin, $2.5 \mu \mathrm{g} \mathrm{mL}^{-1}$ streptomycin, $2.5 \mu \mathrm{g} \mathrm{mL}^{-1}$ amphotericin $\mathrm{B}$, and $50 \mu \mathrm{g} \mathrm{mL}^{-1}$ ascorbic acid. At $\sim 70-80 \%$ confluence, cells were enzymatically detached with $0.05 \%$ trypsin and $0.5 \mathrm{~mm}$ EDTA and seeded at $10^{4}$ cells $\mathrm{cm}^{-2}$. After an attachment period of $24 \mathrm{~h}$, the culture medium was renewed and supplemented with various concentrations $(0.005-500 \mathrm{~mm})$ of the ampicillin-based ILs. Cell cultures were maintained in a $5 \% \mathrm{CO}_{2}$ humidified atmosphere at $37^{\circ} \mathrm{C}$. Cellular viability/proliferation was assessed by MTT assay at days 1, 3, and 5 of the culture. This assay is based on the reduction of 3-(4,5-dimethylthiazol-2-yl)-2,5-diphenyltetrazolium bromide to a purple formazan product by viable cells. Briefly, cultured cells were incubated at $37^{\circ} \mathrm{C}$ with MTT $\left(0.5 \mathrm{mg} \mathrm{mL}^{-1}\right)$ for $4 \mathrm{~h}$. The culture medium was then removed; the stained product was dissolved in DMSO, and absorbance was measured at $\lambda=550 \mathrm{~nm}$ in an ELISA plate reader. Results were expressed as absorbance per square centimeter $\left(A \mathrm{~cm}^{-2}\right) \cdot{ }^{[22]}$ Half-maximal inhibitory concentration $\left(\mathrm{IC}_{50}\right)$ and median lethal dose $\left(\mathrm{LD}_{50}\right)$ values were obtained by nonlinear regression analysis of concentration-effect curves, using GraphPad Prism software (version 2012). ${ }^{[23]}$ The definition of $I C_{50}$ is given by Sebaugh ${ }^{[16]}$ as "the response corresponding to the $50 \%$ control (the mean of the $0 \%$ and $100 \%$ assay controls)" and is used to measure the efficacy of a compound in inhibiting any biochemical or biological function.
$\mathrm{LD}_{50}$ is the median lethal dose and is the amount of material that causes the death of $50 \%$ of a population. ${ }^{[16]}$

Keywords: active pharmaceutical ingredients - ampicillin antitumor agents • ionic liquids • toxicity

[1] Ionic Liquids: Applications and Perspectives (Ed.: A. Kokorin), InTech, Rijeka, 2011.

[2] W. L. Hough, M. Smiglak, H. Rodriguez, R. P. Swatloski, S. K. Spear, D. T. Daly, J. Pernak, J. E. Grisel, R. D. Carliss, M. D. Soutullo, J. H. Davis, R. D. Rogers, New J. Chem. 2007, 31, 1429.

[3] R. Ferraz, L. C. Branco, C. Prudencio, J. P. Noronha, Z. Petrovski, ChemMedChem 2011, 6, 975.

[4] I. M. Marrucho, L. C. Branco, L. P. N. Rebelo, Annual Rev. Chem. Biom. Eng. 2014, 5, 527

[5] R. Ferraz, L. C. Branco, I. M. Marrucho, J. M. M. Araujo, L. P. N. Rebelo, M. N. Ponte, C. Prudencio, J. P. Noronha, Z. Petrovski, MedChemComm 2012, 3, 494.

[6] C. Florindo, J. M. M. Araújo, F. Alves, C. Matos, R. Ferraz, C. Prudêncio, J. P. Noronha, Ž. Petrovski, L. Branco, L. P. N. Rebelo, I. M. Marrucho, Int. J. Pharm. 2013, 456, 553.

[7] V. Kumar, S. V. Malhotra in lonic Liquid Applications: Pharmaceuticals, Therapeutics, and Biotechnology, American Chemical Society Symposium Series, Washington DC, 2010, Chapter 8, pp. 91-102.

[8] V. Kumar, S. V. Malhotra, Bioorg. Med. Chem. Lett. 2009, 19, 4643.

[9] S. V. Malhotra, V. Kumar, Bioorg. Med. Chem. Lett. 2010, 20, 581.

[10] J. Stoimenovski, D. R. MacFarlane, K. Bica, R. D. Rogers, Pharm. Res. 2010, 27, 521.

[11] S. P. M. Ventura, A. M. M. Goncalves, T. Sintra, J. L. Pereira, F. Goncalves, J. A. P. Coutinho, Ecotoxicology 2013, 22, 1.

[12] M. Markiewicz, M. Piszora, N. Caicedo, C. Jungnickel, S. Stolte, Water Res. 2013, 47, 2921.

[13] T. P. Thuy Pham, C.-W. Cho, Y.-S. Yun, Water Res. 2010, 44, 352.

[14] R. F. M. Frade, A. Matias, L. C. Branco, C. A. M. Afonso, C. M. M. Duarte, Green Chem. 2007, 9, 873.

[15] J. Costa-Rodrigues, A. Fernandes, M. H. Fernandes, J. Cell. Biochem 2011, 112, 3704.

[16] J. L. Sebaugh, Pharm. Stat. 2011, 10, 128.

[17] A. P. Freidig, S. Dekkers, M. Verwei, E. Zvinavashe, J. G. M. Bessems, J. J. M. van de Sandt, Toxicol. Lett. 2007, 170, 214.

[18] R. F. M. Frade, A. A. Rosatella, C. S. Marques, L. C. Branco, P. S. Kulkarni, N. M. M. Mateus, C. A. M. Afonso, C. M. M. Duarte, Green Chem. 2009, 11, 1660.

[19] S. Kano, K. Sugibayashi, Pharm. Res. 2006, 23, 329.

[20] R. P. Kiene, Appl. Environ. Microbiol. 1998, 64, 1045.

[21] N. Muhammad, M. I. Hossain, Z. Man, M. El-Harbawi, M. A. Bustam, Y. A. Noaman, N. B. M. Alitheen, M. K. Ng, G. Hefter, C.-Y. Yin, J. Chem. Eng. Data 2012, 57, 2191.

[22] P. S. Gomes, J. D. Santos, M. H. Fernandes, Acta Biomater. 2008, 4, 630.

[23] A. V. Barros, L. M. Araujo, F. F. Oliveira, A. O. Conceicao, I. C. Simoni, M. J. B. Fernandes, C. W. Arns, Acta Sci. Veter. 2012, 10, 1068. 